\title{
Life cycle assessment of future electric and hybrid vehicles: a cradle-to-grave systems engineering approach
}

\author{
Carla Tagliaferri ${ }^{1}$, Sara Evangelisti ${ }^{1}$, Federica Acconcia ${ }^{2}$, Teresa Domenech ${ }^{3}$, Paul Ekins ${ }^{3}$, Diego Barletta ${ }^{2}$, \\ Paola Lettieri ${ }^{1 *}$
}

${ }^{1}$ Chemical Engineering Department, University College London, Torrington Place, London WC1E 7JE, UK

${ }^{2}$ Dipartimento di Ingegneria Industriale, Università di Salerno, Via Giovanni Paolo II, 132, I-84084 Fisciano (SA), Italy

${ }^{3}$ University College London, Institute for Sustainable Resources, Central House, 14 Upper Woburn Place, London WC1H 0NN, UK

*corresponding author: Department of Chemical Engineering, UCL, Torrington Place, Roberts Building, Room 312, London WC1E 7JE, UK. Tel.: +44 (0) 207679 7867; fax: +44 (0) 207383 2348. Email:

\section{p.lettieri@ucl.ac.uk}

\section{Abstract}

Electric mobility is playing an important and growing role in the context of sustainable transport sector development. This study presents the life cycle assessment of an electric car based on the technology of Lithium-ion battery (BEV) for Europe and compares it to an internal combustion engine vehicle (ICEV). According to a cradle-to-grave approach, manufacturing, use and disposal phases of both vehicles have been included in the assessment in order to identify the hot spots of the entire life cycles. For electric vehicles two manufacturing inventories have been analysed and different vehicle disposal pathways have also been considered. Furthermore, the environmental performances of hybrid vehicles have been analysed based on the life cycle models of the BEV and ICEV. The results of the hot spot analysis showed that the BEV manufacturing phase determined the highest environmental burdens mainly in the toxicity categories as a result of the use of metals in the battery pack. However, the greenhouse gas emissions associated with the BEV use phase were shown to be half than those recorded for the ICEV use phase. The trend of the results have also been investigated for future energy mixes: the electricity and diesel mixes for the year 2050 have been considered for the modelling of the use phase of BEV and ICEV.

Keywords: life cycle assessment of electric vehicles; electric battery disposal; future energy scenarios.

\section{Introduction}

The transport sector is one of the most appealing and challenging when tackling the target of emissions reduction: currently, the $\mathrm{CO}_{2}$ emissions in the transport sector are about $23 \%$ of the total antropogenic $\mathrm{CO}_{2}$ emissions worldwide (UNECE 2015). In addition to this, a study commissioned by the World Business Council for Sustainable Development (World Business Council for Sustainable Development 2004) estimates that the number of light-duty vehicles in operation will rise to about 1.3 billion by 2030 and 2 billion by 2050 . Hence, 
there will be a dramatic increase in demand for fuel supplies associated with transport, which raises issues for climate change, urban air quality as well as non-renewable resources depletion. This has pushed towards the development of new technologies in the automotive industry.

One possible solution for decreasing the carbon footprint of the transport sector is the use of biogenic carbon content fuels (such as cellulosic ethanol or soy biofuel) in conventional internal combustion engine vehicles, instead of the regular fuel supply (Samaras and Meisterling 2008). However, the production of bio-fuel has well known drawbacks when applied to large scale, mainly associated with pressure on land that would otherwise be used for agricultural purposes. In addition to this, bio-electricity powered electric vehicles can offer higher mileage per unit of biomass than when liquid biofuels such as ethanol are used in a conventional internal combustion engine (IEA Bioenergy 2011)

The generic term 'electric vehicle' refers to several types of vehicles that differ for the share of electricity used for traction over conventional fuels: purely battery-driven electric vehicles (BEVs), hybrid electric vehicles (HEVs), plug-in hybrid electric vehicles (PHEVs) and extended range electric vehicles (E-REVs). The use of electricity for the transport sector is also promising for having the potential to reduce greenhouse gas emissions compared to ICEVs thanks to the avoided or reduced requirements of diesel or gasoline as fuel supply. According to Zackrisson et al. (2010) the potential savings in GHG range is between $25 \%$ for hybrid EVs, up to $50-80 \%$ for plug-in hybrid EVs and about $90 \%$ for battery EVs. Moreover, a very wide range of road vehicles can use electric power for motion: from heavy duty vehicles- such as hybrid buses and tramways to light duty ones, including city cars, forklift trucks etc. Each type of vehicle can use various battery technologies, such as Lithium-ion battery (Li-ion), Nickel Metal Hydride (NiMH), lead acid, nickel cadmium batteries, each characterised by specific properties (specific power, depth of discharge (DoD), memory effect, number of charges per cycle, etc.).

However, the use of heavy metals for battery manufacturing, the electricity mix used for charging the battery and the disposal of the used battery are key aspects in the life cycle of an electric vehicle that need to be carefully considered under a life cycle approach to identify possible sources of increased environmental impacts. In Wietschel et al. (2013), electric cars are reported to be increasingly penetrating the future fleet market but they are also facing the most technological challenges today. Because of that, the environmental impacts associated with the manufacturing, use phase and end of life of electric cars need to be analysed.

Some environmental assessment studies on EV, differing in scopes and details of analysis, have already been performed. For examples, many (Samaras and Meisterling 2008; Aguirre et al. 2012; Helmers and Marx 2012; Dunn et al. 2012b; Faria et al. 2013) mainly focused on the analysis of the energy requirements and the greenhouse gas emissions throughout the vehicle life cycle. In particular, the latter calculated the energy inputs and $\mathrm{CO}_{2}$ equivalents emissions of a conventional gasoline vehicle, a hybrid vehicle, and a battery electric vehicle for California referring to the aggregated inventory data reported in a model previously developed by the US Argonne National Laboratory (Sullivan et al. 2010; Sullivan and L. 2010); however, a detailed description of the inventory data and model parameters was not available. The same is also true for other two studies (Van den Bossche et al. 2006; Matheys et al. 2008) who reported an aggregated environmental impacts of different electric batteries used for motion, calculated according to the grouping phase of the life cycle assessment (LCA) methodology. Ellingsen et al. (2014) and Bettez et al. (2011a) published the environmental assessment of the manufacturing phase of different types of electric batteries but they did not consider the entire life cycle of the 
vehicles. Conversely, Daimler AG (2009) and Zackrisson et al. (2010) reported the results of LCA studies on batteries used for hybrid vehicles accounting also for the entire life cycle of the vehicles. Finally, the most detailed and complete studies on BEV are those by Notter et al. (2010) and Hawkins et al (2013) that reported the life cycle assessment of the entire life cycle of the vehicle, analysing also different environmental impacts. However, in both studies the results of the disposal phase were entirely based on the Ecoinvent database (Swiss Centre for Life Cycle Inventories 2014).

The purpose of this study is to perform an attributional life cycle assessment of the manufacturing, use and disposal phases of BEVs and hybrid vehicles, and compare it to the life cycle of a conventional vehicle, such as diesel ICEVs. All the components of the vehicle, including the battery system, the glider, and the power train are analysed in the hot spot analysis. As shown before, many LCA studies have been conducted on batteries for electric vehicles. However, very few studies have analysed the entire life cycle of vehicles, including both the battery and the rest of the vehicle and have considered the disposal phase based on an industrially developed technology as done in this study. In addition to this, few studies considered the effect of different energy shares on the environmental impacts of the electric vehicle life cycle. Egede et al. (2015) reported that the electricity mix is a crucial parameter for the LCA calculation and this is also supported by the results reported in Faria et al. (2013) where the electricity mix of different countries in 2013 were considered. However, the latter fails to consider the potential development of the electric vehicle fleet within the projected future energy mixes. Conversely, our study considers referenced projections of the future EU electricity share and therefore contextualises the study of the environmental burdens of electric vehicles to more realistic future scenarios.

\section{Life cycle assessment methodology}

Life cycle assessment is one of the most developed and widely used environmental assessment tools for comparing alternative technologies (Clift et al. 2000; Clift 2013). LCA quantifies the amount of materials and energy used and the emissions and waste over the complete supply chain (i.e. life cycles) of goods and services (Baumann and Tillman 2004). Moreover, it helps to identify the 'hot spots' in the system; i.e. those activities that determine the most significant environmental impact and should be targeted in the first instance, thus enabling identification of more environmentally sustainable options (Clift 2006).

In the Impact Assessment phase, the emissions and inputs quantified in the Inventory phase are translated into environmental impacts. This study focuses specifically on three impact categories - showed in Table 1 - which are considered the most significant for the purpose of this work. However, other impact categories as suggested by ILCD handbook have been analysed in this study (ILCD 2011). For a full list of categories see Supplementary Information.

The global warming potential (GWP) characterises and calculates the impact of greenhouse gases based on the extent to which they enhance radiative forcing. GWP values for specific gases, developed by the Intergovernmental Panel on Climate Change (IPCC), express the cumulative radiative forcing over a given time period following a pulse emission in terms of the quantity of carbon dioxide giving the same effect (IPCC 2007). Following common convention, such as the Kyoto Protocol, the 100-year values have been used here. The abiotic depletion (AD) addresses the environmental problem of the diminishing pool of resources. It focuses on the depletion of non-living resources such as iron ore, crude oil, etc. The measurement unit of abiotic depletion is MJ as the majority of non-renewable resources represent energy sources. The human toxicity 
potential (HTP) reflects the potential harm of chemical species released into the environment, based on both the

114 inherent toxicity of a compound and the potential human exposure.

115 Currently more than thirty software packages exist to perform LCA analysis, with differing scope and capacity:

116 some are specific for certain applications, while others have been directly developed by industrial organisations

117 (Manfredi and Pant 2011). In this study, GaBi 7 has been used (Thinkstep 2015); it contains databases

118 developed by ThinkStep that incorporates industry organisations' databases (e.g. Plastics Europe, Aluminium

119 producers, etc.) and also regional and national databases (e.g. Ecoinvent, US NREL database, etc.).

120 Table 1 Impact categories and indicators used in this study

\begin{tabular}{|c|c|c|c|c|}
\hline Impact categories & Impact Indicator & Acronym & Carachterisation model & Units \\
\hline Climate change & $\begin{array}{l}\text { Global warming } \\
\text { potential }\end{array}$ & GWP & $\begin{array}{l}\text { CML } 2001 \text { baseline (IPCC } \\
\text { 2007) }\end{array}$ & $\mathrm{kg} \mathrm{CO}_{2} \mathrm{eq}$ \\
\hline $\begin{array}{l}\text { Resources depletion } \\
\text { (fossil) }\end{array}$ & Abiotic depletion & $\mathrm{AD}$ & $\begin{array}{l}\text { CML } 2001 \text { baseline (Guinée } \\
\text { et al., 2001) }\end{array}$ & MJ \\
\hline Human toxicity & $\begin{array}{l}\text { Human toxicity } \\
\text { potential }\end{array}$ & HTP & $\begin{array}{l}\text { USEtox model (Rosembaum } \\
\text { et al., 2008) }\end{array}$ & $\begin{array}{l}\mathrm{kg} \mathrm{DCB}^{1} \\
\mathrm{eq}\end{array}$ \\
\hline
\end{tabular}

Note: ${ }^{1}$ DCB: dichlorobenzenes.

\section{3. Goal and scope definition and system boundaries}

123 The main goal of this paper is to perform an attributional life cycle analysis with a consequential approach of a 124 battery electric vehicle (BEV), and compare it with the life cycle impacts of a more conventional technology, such as an internal combustion engine diesel vehicle (ICEV). Moreover, a hot spot analysis to identify the steps with the highest impacts to the total life cycle is presented. The two models for ICEV and BEV are used to analyse the environmental impacts of different types of hybrid vehicles. Two different scenarios are also considered for the end-of-life phase: a 'high recycling rate' scenario - where the total vehicle is assumed to be recovered in EU at its EoL; and a 'low recycling rate' scenario, where a fraction of the vehicle is assumed to be landfilled outside EU borders. While the former is more unrealistic, the latter represents the current situation of the vehicle EoL market in Europe where part of the fleet exits the EU borders (Mehlhart et al. 2011). A final scenario analysis considers future EU energy technologies and mixes.

Figure 1 shows the boundary of the system analysed. Three different phases have been considered in the analysis: the manufacturing phase - which includes the production of the batteries and all the single components up to the glider; the use phase - which includes the production of electricity needed to recharge the battery; the end of life phase - which includes the reprocessing of the vehicle including the battery, up to the recovery of some metals. The same phases have also been considered for the ICEV. For all the phases, indirect, direct and avoided burdens are considered in the life cycle models according to EU-site specific inventories (Behrens et al. 2013) and allocation is performed using the method of system expansion. Transport of the different components 
to the production and dismantling sites- manufacturing and disposal phases - is considered negligible as already analysed in literature (Hawkins et al. 2013).

The functional unit used in this study is the function of $1 \mathrm{~km}$ driven by one vehicle (car). To account for the manufacturing and the disposal phase, an assumption of the total $\mathrm{km}$ driven in the entire life cycle of the vehicle was made. Based on previous studies (Majeau-Bettez et al. 2011a; Ellingsen et al. 2014), a total life cycle of $150,000 \mathrm{~km}$ is considered for both BEVs and ICEVs.

Table 2 Reference vehicles for the life cycle assessment of BEV, ICEV and hybrid vehicles

\begin{tabular}{|l|l|l|}
\hline Technology & Model & Fuel \\
\hline Electric(100\%) EV & Nissan Leaf & $/$ \\
\hline
\end{tabular}

\section{Life cycle inventory}

In this section, the inventory models built for the BEV and ICEV are presented. The inventory was based on a mix of data coming from several literature studies published in the recent years on BEVs and plug-in vehicles, existing dataset (Swiss Centre for Life Cycle Inventories 2014; Thinkstep 2015), and reports and presentation from private companies (Umicore 2015).

The vehicle's models were based on the most promising and most popular commercial vehicles currently sold on the market (see Table 2). For the BEV, a Nissan leaf equipped with a Li-ion battery technology was assumed as reference while for the ICE a Toyota Yaris was assumed as reference vehicle because of the same category as the Nissan Leaf.

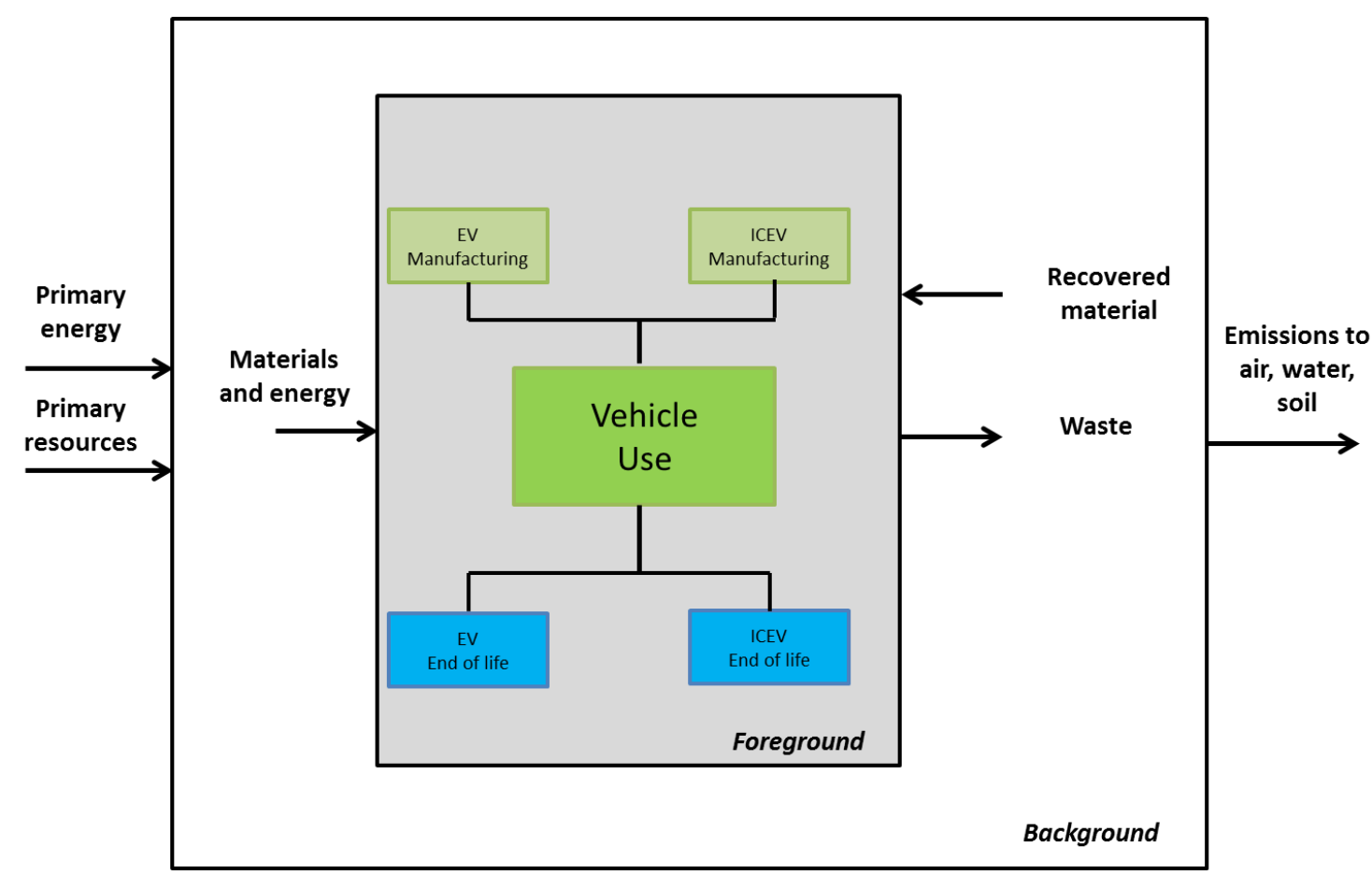

Figure 1 System boundary 


\begin{tabular}{|l|l|l|}
\hline Hybrid(30\%) HEV & Yaris Hybrid & Diesel \\
\hline Hybrid(60\%) P-HEV & Toyota Prius Plug-in & Diesel \\
\hline 'Hybrid'(90\%) E-REV & Toyota Prius & Diesel \\
\hline Internal Combustion Engine ICEV & Toyota Yaris & Diesel \\
\hline
\end{tabular}

158

159

160

161

162

163

164

165

166

167

168

169

170

171

172

173

174

\subsection{Manufacturing}

The vehicle is composed by several units, which can be divided in sub-units up to the single component. The two main macro units which have been considered in the vehicle models are the powertrain (electric motor and battery system for the BEV and the internal combustion engine for the ICEV) and the glider. For both ICEV and BEV, the model for the glider was based on Ecoinvent 2.1 (Swiss Centre for Life Cycle Inventories 2014).

\section{$\underline{\text { Battery electric vehicle }}$}

Two different models were considered for the manufacturing of the BEV, in order to test the robustness of the results. The first model (EV I) was based on the study published by Bettez et al. (2011a). In their study, Bettez et al. based the LCA inventory on average literature data for the manufacturing of the battery. The second model (EV II) was based on the study published by Ellingsen et al. (2014). Their inventory was based on an existing battery, and the dataset for this was built using a mix of average and commercial data supplied by the battery manufacturing company (Miljøbil Grenland 2012).

The powertrain of the battery electric vehicle includes all the units of the BEV excluding the glider. In total, the weight of the glider and the powertrain excluding the battery was $1307 \mathrm{~kg}$ and $1271 \mathrm{~kg}$ for EVI and EVII, respectively, in order to match a total weight for the BEV equal to the Nissan leaf. The weight of the Li-Ion battery was 214 and $250 \mathrm{~kg}$ for EVI and EVII, corresponding to a specific power of 112 and $106 \mathrm{Wh} / \mathrm{kg}$. Table 3 shows the characteristics of the Nissan Leaf assumed in this study.

\begin{tabular}{|l|l|r|}
\hline \multicolumn{3}{|c|}{ Nissan Leaf } \\
\hline Curb weight & $\mathrm{kg}$ & 1521 \\
\hline Length & $\mathrm{cm}$ & 444.5 \\
\hline Width & $\mathrm{cm}$ & 177 \\
\hline Height & $\mathrm{cm}$ & \multicolumn{2}{|c|}{} \\
\hline Body style & & $\begin{array}{l}\text { 5-door } \\
\text { hatchback }\end{array}$ \\
\hline $\begin{array}{l}\text { Electric } \\
\text { motor }\end{array}$ & $\mathrm{kW}$ & 24 \\
\hline $\begin{array}{l}\text { Battery (Li- } \\
\text { Ion) }\end{array}$ & $\mathrm{kWh}$ & 117 \\
\hline Range & $\mathrm{km}$ & \multicolumn{2}{|c|}{} \\
\hline
\end{tabular}




\begin{tabular}{|l|l|l|}
\hline & $\left(\right.$ EPA $\left.^{1}\right)$ & \\
\hline & $\begin{array}{l}\mathrm{km} \\
\left(\mathrm{NEDC}^{2}\right)\end{array}$ & 175 \\
\hline $\begin{array}{l}\text { Energy per } \\
\mathrm{km}\end{array}$ & $\begin{array}{l}\text { Wh } \\
(\mathrm{NEDC})\end{array}$ & 173 \\
\hline
\end{tabular}

Table 3 Characteristics of the Nissan Leaf assumed as BEV in this study (Nissan 2015)

176

The battery pack is the core of the BEV; this is composed by four units: the cooling system; the battery cell; the packaging; and the battery management system (BMS) (for an example see Figure 2). The modelled battery pack consists of 48 modules and each module contains four battery cells for a total of 192 cells. As an example, the weight distribution of each battery pack as assumed in this study for EVII is reported in Figure 2; for both models, the main component of the battery pack is the cell. The thermal management of the battery is done by the cooling system. This is made by six sub-components: radiator, manifolds, clamps \& fasteners, pipe fitting, thermal gap pad, and coolant (Ellingsen et al. 2014). The main component is the aluminium radiator, which accounts for the $30 \%$ of the total aluminium used in the battery system (Ellingsen et al. 2014). It is worth noticing that originally Majeau-Bettez et al. (2011a) did not include the cooling system as a component of the battery pack. For a fair comparison between the two models, we included the cooling system as defined by Ellingsen et al. (Ellingsen et al. 2014) in the EVI model.

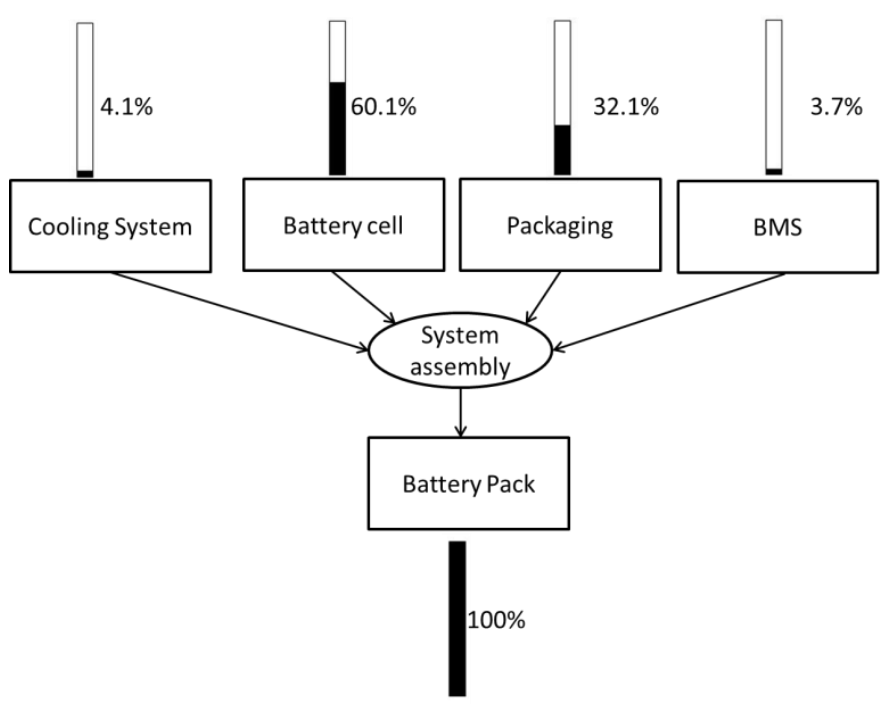

Figure 2 Battery pack weight distribution for EVII. Adapted from the literature (Ellingsen et al. 2014)

Several compositions for the cathode of a Li-ion battery were studied in the literature (Goodenough and Park 2013): LiMn2O4 (LMO), LiFePO4 (LFP), Li(NiCoAl)O2, and Li(NixCoyMnz)O2 (NCM), where x, y, and z denote different possible ratios. However, the models (EVI and EVII) developed in this study are based on a LiNi0.4Co0.2Mn0.4O2 battery according to the characteristics of the Nissan Leaf. The main differences amongst the EVI and EVII model are in terms of materials and quantities involved in the manufacturing phase, and in the energy assumed for the manufacturing of the battery system. The main inventory data and differences in cell manufacturing are reported in Table 4. 


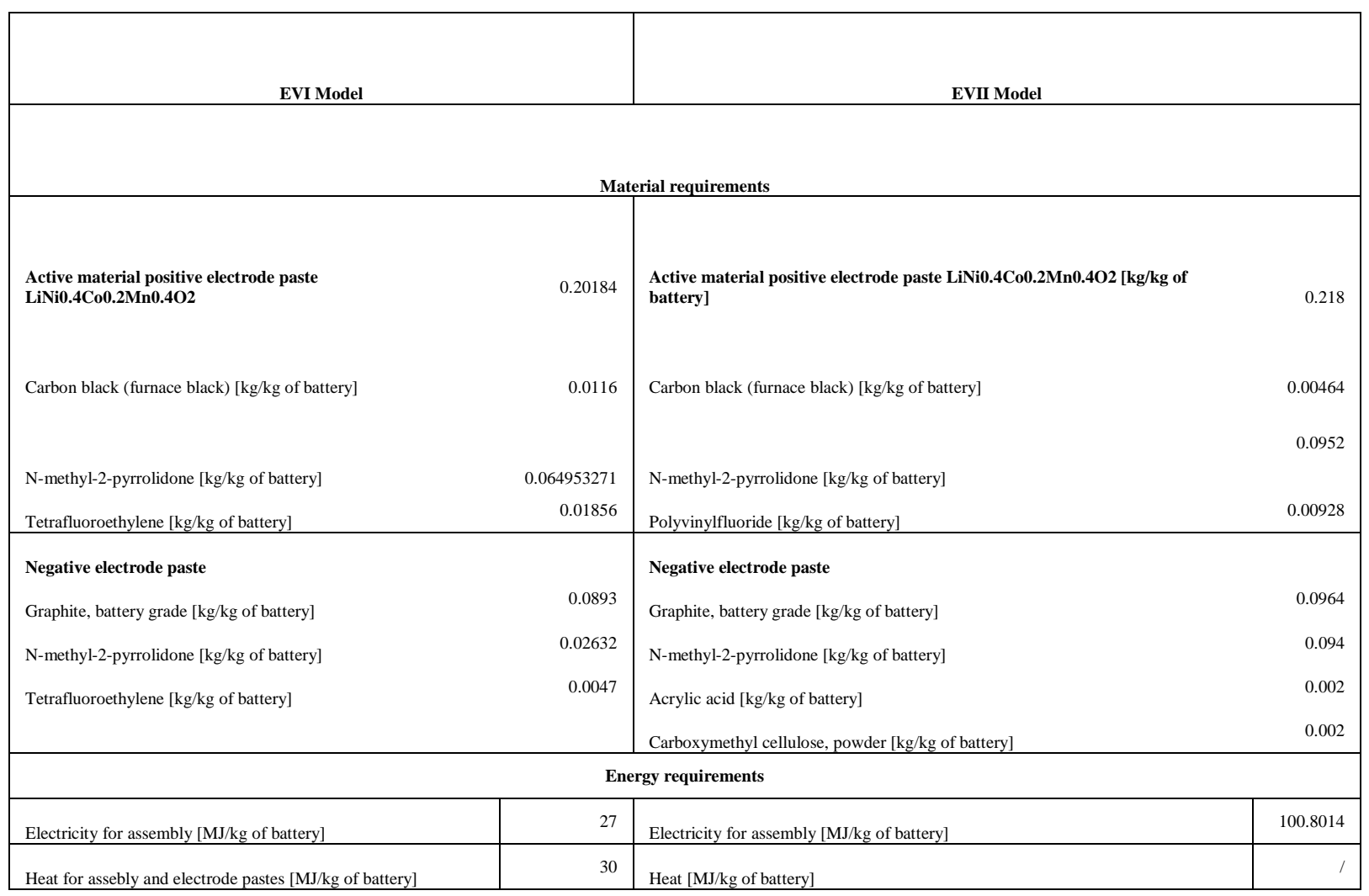

Table 4 Main inventory for the two BEV models in terms of materials and energy requirements

The EVI and EVII models differ basically in chemicals used (except the active material which is the same) and their quantities and structure complexity. For both $\mathrm{Li}$-ion batteries, the anode is composed primarily of graphite; acrylic acid and carboxymethyl cellulose in EVII substitute tetrafluoroethylene in EVI. The assumed energy required for the manufacturing of the battery system can vary greatly amongst the literature, from 3.1 to 1060 $\mathrm{MJ} / \mathrm{kWh}$ (Ellingsen et al. 2014). In particular, this figure is considerably different for the two battery models analysed. Ellingsen et al. (2014) assumed an energy requirement of $586 \mathrm{MJ} / \mathrm{kWh}$ based on industrial data, while Majeau-Bettez et al. (2011a) reported an energy consumption between 371 and $473 \mathrm{MJ} / \mathrm{kWh}$ based on industry reports. Moreover, while Ellingsen et al. (2014) refers to the energy required to manufacture the battery cell, the figure proposed by Majeau-Bettez et al. (2011a) included also the energy for the battery system assembling. The electricity assumed for the manufacturing of the cell in EVI includes the coating of the electrode pastes to metallic foils used as current collectors, welding of current collectors to tabs, filling of electrolyte, and initial charging of the finished cell. However, as reported by Ellingsen et al. (2014) the main consumption is due to the operation of various dry rooms that are vital to the quality of the battery cells. This explains also the difference in energy consumption assumed in EVI and EVII. In order to ensure the comparability of the results, the energy accumulated by the battery and then delivered to

213 the powertrain, was fixed to $24 \mathrm{kWh}$ (Genikomsakis et al. 2013; Nissan 2015) for the two BEV models. The two

214 batteries have equal charge capacity but different weight (214 $\mathrm{kg}$ for the EVI vs $250 \mathrm{~kg}$ for EVII). 
216 The inventory for the ICEV manufacturing phase is based on Ecoinvent 2.2 database (Swiss Centre for Life

217 Cycle Inventories 2014). The model was built according to a life cycle inventory analysis based on a "Golf A4,

2181.41 Otto" (Leuenberger and Frischknecht 2010). The whole life cycle inventory as reported by Ecoinvent was

219 scaled up to match the total weight of the Toyota Yaris, which was $1500 \mathrm{~kg}$. The emissions to air during the

220 manufacturing process are assumed to result from stationary combustion processes at the factory site (Swiss

221 Centre for Life Cycle Inventories 2014).

$222 \quad 4.2$ Use

223 In the use phase we have accounted for the emissions due to the use of the vehicles (direct emissions) and for 224 the emissions due to the production of the fuel (indirect emissions), i.e. electricity for BEV and diesel for ICEV.

\section{$\underline{\text { Battery electric vehicle }}$}

The energy consumption reported in the literature varies significantly depending on the assumption of battery cycles and lifetime. In this study, we assumed a lifetime of $150,000 \mathrm{~km}$ for the BEV, in line with literature (Notter et al. 2010). The electric energy needed to drive $1 \mathrm{~km}$ was assumed equal to $0.56 \mathrm{MJ} / \mathrm{km}$, based on Ecoinvent 2.2, with a powertrain efficiency of $80 \%$ in a standard driving cycle (New European Driving Cycle, NEDC). This is similar to the consumption reported in the literature (Notter et al. 2010), which shows an electrical consumption of $17 \mathrm{kWh}$ for $100 \mathrm{~km}$, referred to a combination of the urban $(12.8 \mathrm{kWh} / 100 \mathrm{~km})$ and extra-urban $(16.8 \mathrm{kWh} / 100 \mathrm{~km})$ energy consumption in a NEDC, plus the consumption of heating and air conditioning during one year. A slightly lower electrical consumption was assumed by other authors (MajeauBettez et al. 2011a; Ellingsen et al. 2014), corresponding at 3,000 cycles for the battery lifetime, and equals to $0.5 \mathrm{MJ} / \mathrm{km}$. No battery package replacement was considered during the vehicle life (Notter et al. 2010).

In this study we have assumed an electricity production mix for the BEV use phase which is representative of the European electricity grid. The inventory was based on Thinkstep database (Thinkstep 2015) and it is dominated by nuclear energy (mainly from France), hard coal and natural gas which alone constitute around $64 \%$ of the total primary energy. The sensitivity of the model to the electricity mix is considered in the future energy scenarios analysis.

242 For the ICEV use phase we have assumed the same lifetime of the BEV, which is 150,000 km. The fuel 243 consumption was $50.04 \mathrm{~mL} / \mathrm{km}$, based on Ecoinvent 2.2 (Spielmann et al. 2007; Swiss Centre for Life Cycle 244 Inventories 2014). A EURO 5 vehicle was modelled, in accordance to the most recent European regulations on 245 the subject.

246 The model for the diesel production was based on Thinkstep database (Thinkstep 2015). The data set covered 247 the entire supply chain of the refinery products. Country / region specific downstream (refining) technologies, 248 feedstock (crude oil) and product (diesel fuel, etc.) properties, like sulphur contents, were considered. The sensitivity of the model to the diesel mix is considered in the future energy scenarios. 
251 In the disposal phase models of the ICEV and BEV, the valuable outputs considered by system expansion are the metals: mainly nickel, cobalt, manganese, aluminium, copper and steel. The latter is the main component, in weight, of the glider; conversely, nickel, cobalt and manganese are mainly found in the battery pack of the BEV. The recycling of each of the previous metal was considered together with the processes required for recovery. For the ICEV disposal, precious metals have been included in the assessment according to Ecoinvent (Swiss Centre for Life Cycle Inventories 2014).

257

A scenario analysis was performed on the disposal phase of BEV and ICEV. In the 'high recycling rate' scenario the entire vehicle fleet was assumed to be recycled and disposed within the EU borders according to the later described EoL. Conversely, in the 'low recycling rate' scenario only $57 \%$ of the vehicle fleet was assumed to be disposed in EU (Mehlhart et al. 2011); part of the fleet was considered to be sold outside the EU borders (Mehlhart et al. 2011) and track was lost of it. However, in order to account for the EoL of these vehicles, an assumption was made on their final disposal: in the 'low recycling rate' scenario $43 \%$ of the fleet was assumed to end up in a material landfill outside EU. To model this, the 'Landfill of ferro metals' process was considered.

\section{$\underline{\text { Battery electric vehicle }}$}

265

266

267

268

269

270

271

272

273

274

275

276

277

278

279

280

281

282

283

284

Two steps have been considered for the end of life treatment of BEV. The first refers to the disposal of the glider and the power train excluding the battery and the model for this is based on Ecoinvent v.2.2; the second, involving the battery disposal after dismantling, has been modelled according to currently used technologies in specialised industries (Umicore 2015).

The modelled process for the battery disposal firstly involves a single-furnace pyro-metallurgical treatment method for the treatment of Li-Ion batteries and Li-polymer cells, as well as nickel metal hydride (NiMH) batteries (Vadenbo 2009). The main focus of the process is the recovery of cobalt and/or nickel. Cobalt is commonly found in lithium-ion and lithium-polymer batteries, whereas nickel is mainly introduced into the process through the treatment of NiMH batteries. Publicly available data for the pyro-metallurgical process (Vadenbo 2009; Dunn et al. 2012a; Umicore 2015) and the battery disposal process (Hischier and Gallen 2007) have been put together to build a novel battery disposal model. The process for the battery disposal and the relative inventory is reported in Figure 3. Material recycling is also considered.

The slag is mainly formed by compounds containing aluminium (Al), silicon ( $\mathrm{Si}$ ), calcium (Ca) and to some extent iron $(\mathrm{Fe})$. In the process, lithium also ends up in the slag in the form of lithium oxide. The slag can be used in the construction or concrete industry (Vadenbo 2009). However, in this model, slag use was not considered because the amount of the slag produced compared to the weight of the entre vehicle is negligible. The alloy fraction is predominantly made up of residual iron, copper, cobalt, and possibly nickel. The alloy is subsequently leached with sulfuric acid in a hydrometallurgical step which extracts metals like cobalt, copper, nickel and iron (Vadenbo 2009). Hence, the model has included two pathways: pyro-metallurgical treatment and hydrometallurgical treatment and the allocation of the two pathways has been done at $50 \%$ each. 
The recovery rate of the metals from the pyro and hydrometallurgical processes was based on data elaborated by different authors in the literature (Vadenbo 2009; Dunn et al. 2012a). Considering $1 \mathrm{~kg}$ of Li-Ion battery, these recovery rates for the following metals were considered:

- $\quad 7.7 \%$ Co (Pyro)

- $13.6 \%$ Co (Hydro)

- $\quad 9.6 \% \mathrm{Cu}$ (Pyro)

- $10.8 \%$ Steel (Pyro)

- $6.6 \%$ Steel (Hydro)

- $6 \% \mathrm{Ni}$ (Hydro)

To account for the avoided burdens due to the recovery of these metals, primary production processes were considered in the system expansion according to the market recycling rates (Graedel 2011; Thinkstep 2015).

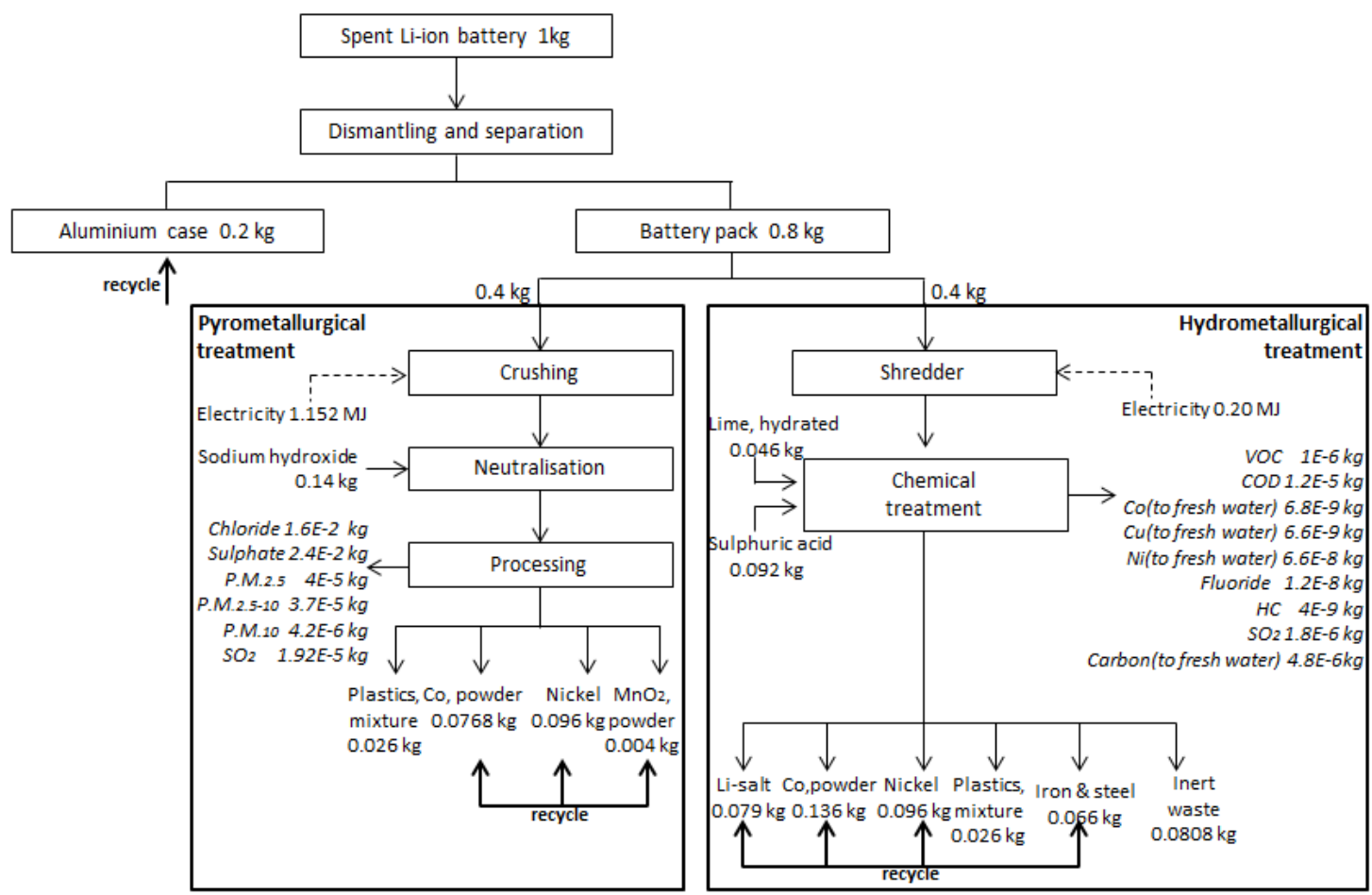

Figure 3 Process flow chart for disposal of lithium-ion battery. This model was adapted and built on the base of the data available in literature (Hischier and Gallen 2007; Vadenbo 2009; Dunn et al. 2012a; Umicore 2015) accounted for $100 \%$ recycling of aluminium, copper and steel contained in the vehicle. The rest of the materials was assumed to be sent to an incineration plant after dismantling (Swiss Centre for Life Cycle Inventories 2014). 

models. As shown in Table 2, the hybridization factors - that represents the percent of the electric part of powertrain out of the total weight of the powertrain- has been changed between $30 \%$ and $90 \%$ : the chosen values were $30 \%$ for the HEV, $50 \%$ for the pHEV and $90 \%$ for the E-REV according to the different vehicle technologies reported in Table 2. Table 2 also shows the reference vehicles; Toyota Yaris Hybrid was chosen for the hybrid vehicle and the Toyota Prius for both plug-in hybrid and extended range electric vehicles. Those vehicles normally use gasoline when running on the internal combustion engine; the environmental impacts of gasoline use have been computed even though the results for this case are not reported. This analysis showed that the environmental impacts associated with the use of gasoline in hybrid car did not significantly differ from the environmental impacts of hybrid vehicles run on diesel. Hence, to allow a fairer comparison with the ICEV, we assumed that the required fuel was diesel also when analysing hybrid vehicles.

\subsection{Scenario analysis: future energy mix}

The use phase environmental impacts of the ICEVs and BEVs are also compared considering future EU energy mix. For the production of the electricity requirements of the BEV, the EU electricity mix of 2050 was considered according to the data reported in the literature (Behrens et al. 2013). Conversely, for the ICEV we assumed that the diesel mix in 2050 will be made up by $72.8 \%$ of conventional diesel and $27.2 \%$ of biodiesel according to the IEA (International Energy Agency 2011). Two models were built to calculate the impacts of the electricity production and diesel production 2050 and then these impacts were added up to the use phase of the two types of vehicle. The electricity mix from 2015 to 2050 shows a decrease of energy from fossil sources (about $-6 \%$ lignite, $-1 \%$ peat, $-9 \%$ hard coal, $-0.5 \%$ coal gases, $-1 \%$ heavy fuel oil and $-5 \%$ natural gas), a $6 \%$ increase of nuclear and an increase of all renewable sources (about $+3.5 \%$ biomass, $+2 \%$ biogas, $+1.8 \%$ waste, $+1.6 \%$ hydro, $+8.5 \%$ wind, $+2 \%$ photovoltaic, slightly increase solar thermal). The biodiesel production was modelled according to the soybean-biodiesel model reported in Ecoinvent database (Swiss Centre for Life Cycle Inventories 2014).

\section{Results}

\subsection{Normalised results}

Table 5 shows the normalised results of the 'high recycling rate' scenarios (assumed as the baseline) for EVI, EVII and ICEV according to the functional unit (i.e. $1 \mathrm{~km}$ driven per vehicle). The total impacts of the three cases have been normalised using the regionalised CML European factors reported in the supplementary information (Thinkstep 2015).

\begin{tabular}{|c|c|c|c|c|}
\hline Total normalized impacts & $E_{E V I}$ & ${ }_{E V I I I}$ & $I C E$ & $\mathrm{HEV} 30 \%$ \\
\hline Abiotic Depletion (ADP elements) & $5.24 \mathrm{E}-13$ & $1.79 \mathrm{E}-13$ & $5.64 \mathrm{E}-14$ & $9.31 \mathrm{E}-14$ \\
\hline Abiotic Depletion (ADP fossil) & $3.77 \mathrm{E}-14$ & $3.80 \mathrm{E}-14$ & $6.65 \mathrm{E}-14$ & $5.79 \mathrm{E}-14$ \\
\hline Acidification Potential ( $\mathrm{AP}$ ) & $3.57 \mathrm{E}-14$ & $3.76 \mathrm{E}-14$ & $3.87 \mathrm{E}-14$ & $3.84 \mathrm{E}-14$ \\
\hline
\end{tabular}




\begin{tabular}{|c|c|c|c|c|}
\hline Eutrophication Potential (EP) & $9.76 \mathrm{E}-15$ & $7.64 \mathrm{E}-15$ & $9.62 \mathrm{E}-15$ & $9.03 \mathrm{E}-15$ \\
\hline Freshwater Aquatic Ecotoxicity Pot. (FAETP inf.) & $1.62 \mathrm{E}-12$ & $1.56 \mathrm{E}-12$ & $8.86 \mathrm{E}-14$ & $5.31 \mathrm{E}-13$ \\
\hline Global Warming Potential (GWP 100 years) & $2.30 \mathrm{E}-14$ & $2.13 \mathrm{E}-14$ & $3.21 \mathrm{E}-14$ & $2.89 \mathrm{E}-14$ \\
\hline Human Toxicity Potential (HTP inf.) & $1.75 \mathrm{E}-13$ & $1.42 \mathrm{E}-13$ & $8.36 \mathrm{E}-14$ & $2.91 \mathrm{E}-14$ \\
\hline Marine Aquatic Ecotoxicity Pot. (MAETP inf.) & $4.06 \mathrm{E}-12$ & $3.16 \mathrm{E}-12$ & $8.70 \mathrm{E}-13$ & $1.01 \mathrm{E}-13$ \\
\hline Ozone Layer Depletion Potential (ODP, steady state) & $3.09 \mathrm{E}-14$ & $2.02 \mathrm{E}-16$ & $1.28 \mathrm{E}-16$ & $1.56 \mathrm{E}-12$ \\
\hline Photochem. Ozone Creation Potential (POCP) & $3.14 \mathrm{E}-14$ & $3.25 \mathrm{E}-14$ & $-5.35 \mathrm{E}-14$ & $1.50 \mathrm{E}-16$ \\
\hline Terrestric Ecotoxicity Potential (TETP inf.) & $8.36 \mathrm{E}-15$ & $8.23 \mathrm{E}-15$ & $1.36 \mathrm{E}-14$ & $-2.77 \mathrm{E}-14$ \\
\hline
\end{tabular}

Table 5 Normalised results of the 'high recycling rate' scenarios for EVI, EVII and ICEV. The normalisation was performed according to the European regionalised impacts reported in the GaBi database (EU25+3, year

2000, incl biogenic carbon (region equivalents))

The impact indicators related to water (MAETP and FAETP) of EVI and EVII are significantly higher than all other normalised impact indicators; the HTP and the ADP element follow in order of magnitude. The reason of the increased values of those results for the EV models has to be found in the use of precious and non-precious metals during manufacturing. It is common that LCA analysis of processes involving the use of metals show high impacts in the water-related categories (Pizzol et al. 2011). This is related to the extraction and processing of the metal itself. In LCA analysis, the MAETP is sometimes analysed but usually the FAETP is the preferred category for the hot spot analysis as it refers to fresh water impacts; the MAETP is not usually included in the analysis also because the emissions to environment contributing to the FAETP are very similar to those contributing to the MAETP; hence there is no need for giving the same information twice.

In LCA, the normalisation of the results is often used to identify the relatively significance of the impact categories and those that score the highest in the normalised results are usually further discussed in the hot spot analysis. However, according to the following reasons, in this work we decided to analyse the ADP fossil, HTP and GWP categories even though they do not determine the highest normalised impacts (a detailed break-down of all the other impact categories is reported in the supplementary information). In this study, more detailed results are reported for the GWP because in the western countries, policies are rarely constraining impacts on water resources as a result of the increased focus on carbon emissions and global warming; GWP was chosen as primary indicator because the majority of 'green policy' and targets for climate change are set on greenhouse gas emissions without specifically looking at other indicators or water impacts. The ADP fossil is also analysed to quantify the impact on depletion of fossil resources and thus on use of primary energy; furthermore, the HTP is considered because of the impact of this category on human health. All other environmental indicators are reported in the supplementary information for further information.

\subsection{Base scenario}

Figure 4 shows the GWP of the different technologies analysed for the high recycling rate scenario; the total impacts are broken down into the manufacturing, use and disposal phases and the results are reported for the functional unit. 
The total GWPs of the two EV models are very similar $\left(0.12 \mathrm{~kg}\right.$ of $\mathrm{CO}_{2}$ eq for EVI and $0.11 \mathrm{~kg}$ of $\mathrm{CO}_{2}$ eq for EVII) whereas the GWP of the ICEV is $45 \%$ higher $\left(0.16 \mathrm{~kg}\right.$ of $\left.\mathrm{CO}_{2} \mathrm{eq}\right)$. The higher GWP of the ICEV is due to the higher impact associated with the use phase: the disposal phase of all models is almost the same; the manufacturing phase of the ICEV determines the lowest GWP and hence, it is the use phase to determine the total trend of the results for the ICEV. The higher GWP of the use phase of the ICEV model is associated to the greater amount of greenhouse gas emitted during the use of diesel as fuel when compared to the production and use of the current EU electricity mix for electric vehicles. For all models the use phase determines the major contribution to the total GWP (61\% for EVI, $66 \%$ for EVII, $89 \%$ for ICEV and $80 \%$ for the HEV). Furthermore, for all the scenarios analysed the disposal phase determines a benefit contribution to the environment thanks to the allocation of avoided burdens according to the system expansion method adopted in this work. However, this phase accounts for both the 'disruptive' burdens associated with the reprocessing and the 'beneficial' burden associated with recycling of metal: the association of these two phases results in the values for the disposal phase reported in Figure 4. Overall the disposal phase does not strongly contribute to the total environmental burdens of the technologies analysed as the benefit of metal recycling are reduced by the burdens of the energy intensive reprocessing processes.
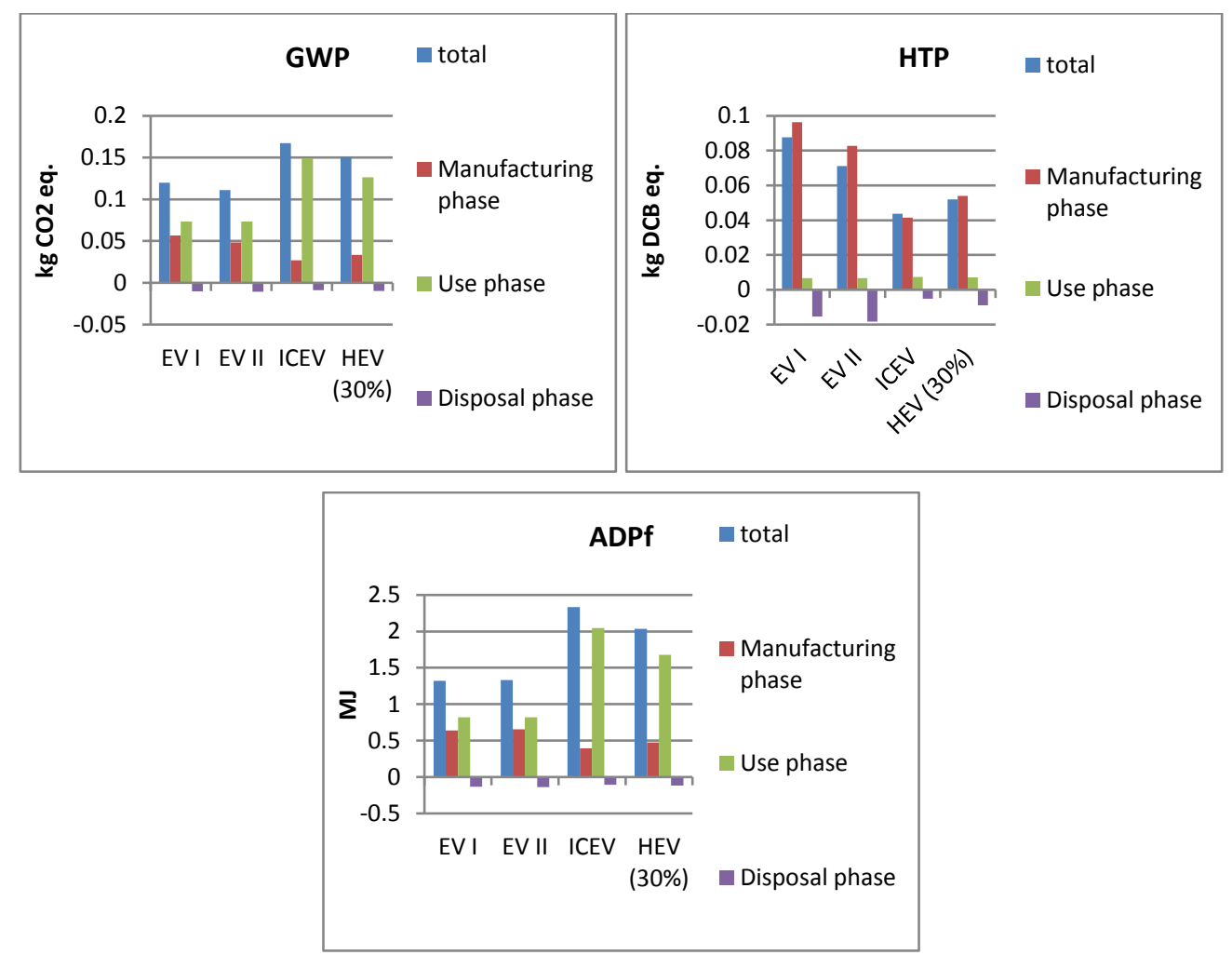

Figure 4 GWP, HTP, ADP of the EVI, EVII, ICEV and HEV (30\%) for the high recycling rate scenario

The manufacturing phase of the EVs determines a higher GWP than the manufacturing phase of the ICEV. Therefore, a further analysis has been performed on the manufacturing phases of the two EV models: about half of the total GWP of the manufacturing phase is due to the manufacturing of the battery pack. A detailed hot spot analysis of the EV battery pack model is presented in Figure 5 for EVI and EVII. The main contributor to the GWP of the battery pack for EVI is the manufacturing of the positive electrode paste as also found in previous works (Majeau-Bettez et al. 2011b). In particular, the indirect burdens associated with the production of the 
tetrafluoroethylene- a chemical used for the manufacturing of this paste- contribute for $78 \%$ to the GWP of the positive electrode paste. A different hot spot analysis is shown for the manufacturing of the battery pack for EVII (Figure 5). For this case, the energy used for the battery assembly determines more than 55\% of the total GWP of the battery pack. Overall the manufacturing phase is a significant burden of the total GWP of an EV and it is comparable to the use phase.

The total ADP is reported in Figure 4. The trend of the results is the same as the GWP. The main contribution to the total depletion of energy resources is the use phase; particularly for the case of ICEV, this is associated to the diesel consumption (hence fossil resources). For the EV models, the impact of the manufacturing phase is comparable to the impact of the use phase and the burden is almost equally spread among the battery manufacturing and the manufacturing of the rest of the vehicle. The energy requirements for the battery assembly are the main contributors to both the ADP of EVI and EVII (the energy requirements for the battery assembly determine $37 \%$ of the total ADP of battery manufacturing for EVI and 52\% of the total ADP of battery manufacturing for EVII) as shown in Figure 5.

402 A different trend of the results is shown for the HTP in Figure 4: the total HTP of the two EV models is higher 403 than the total HTP of the ICEV model in opposition to what has been shown for ADP and GWP. The manufacturing phases of the EVs are the main contributors to this indicator. The processes associated with the chemical and metals production used in the manufacturing phase determine more emissions contributing to the toxicological impacts than the emissions associated with the production of electricity required during the electric vehicle use. In opposition to what reported for the other indicators, the HTPs of the EVI and EVII disposal phases are more than double than the disposal phase of the ICEV. The detailed hot spot analysis on the HTP of the batteries manufacturing is reported in Figure 5 .

Further aggregated results for the base scenario of EVI, EVII and ICEV are reported in the supplementary information where all environmental indicators are shown. The hot spot analysis of the EVI, EVII and ICEV for

412 all environmental indicators is also reported in the supplementary information and the burdens of the manufacturing, use and disposal phases are identified.
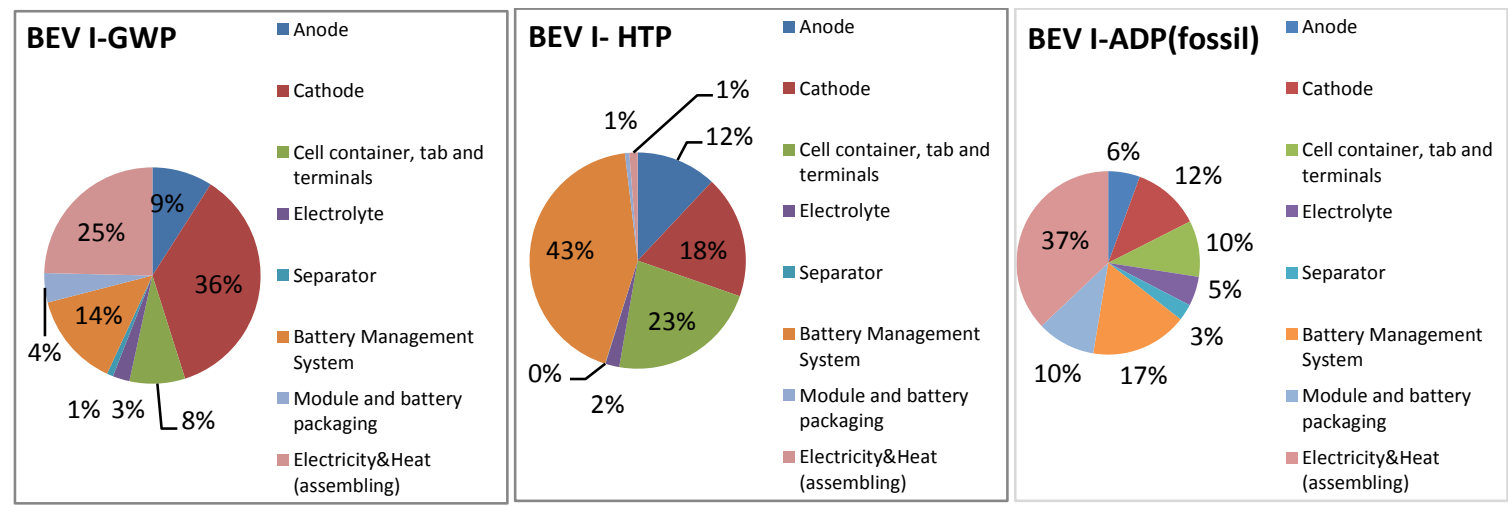

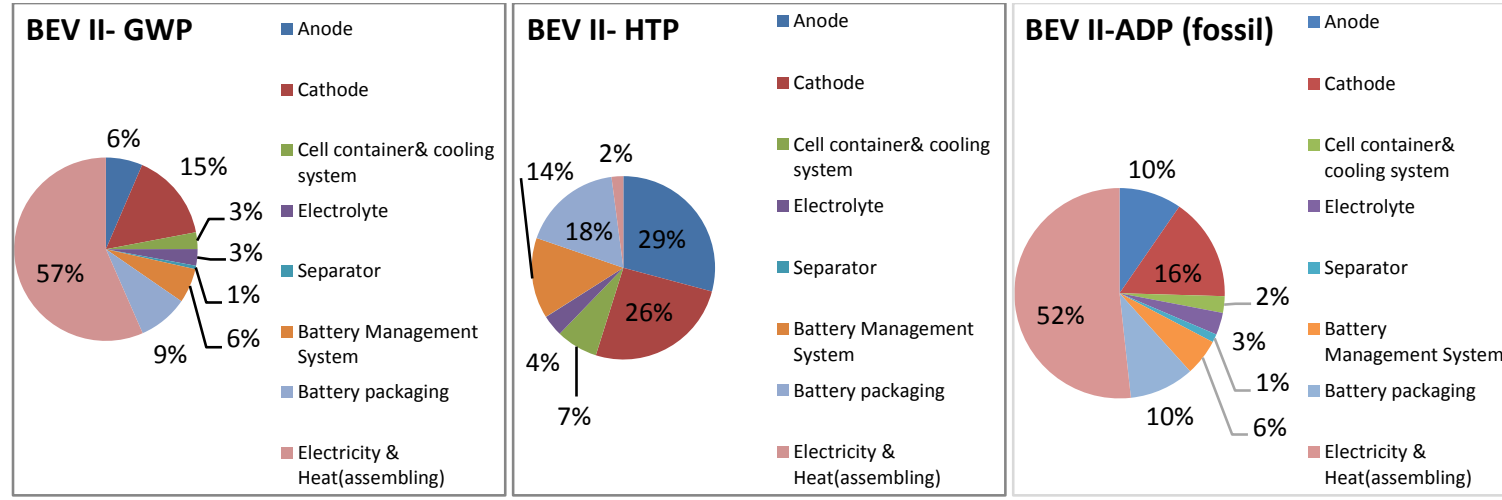

Figure 5 Hot spot analysis of the manufacturing phases for EVI and EVII

\subsection{Scenario analysis: disposal phase}

418 A scenario analysis has been performed on the disposal phase: in previous results the high recycling rate has 419 been considered whereas the results according to the modelling of the low recycling rate are reported in Figure 420 6. The GWP and HTP results for EVI, EVII, HEV (30\%) and ICEV are reported for comparison. As shown 421 previously, the disposal phase is not the major contribution to the total environmental impacts. Therefore, a change of the modelling assumptions according to the low recycling rate scenarios does not determine a significant variation of the results. This means that whether the vehicle fleet is entirely disposed in EU countries or a proportion is disposed outside the EU boundaries, the environmental impacts of the vehicle life cycle does not change significantly.
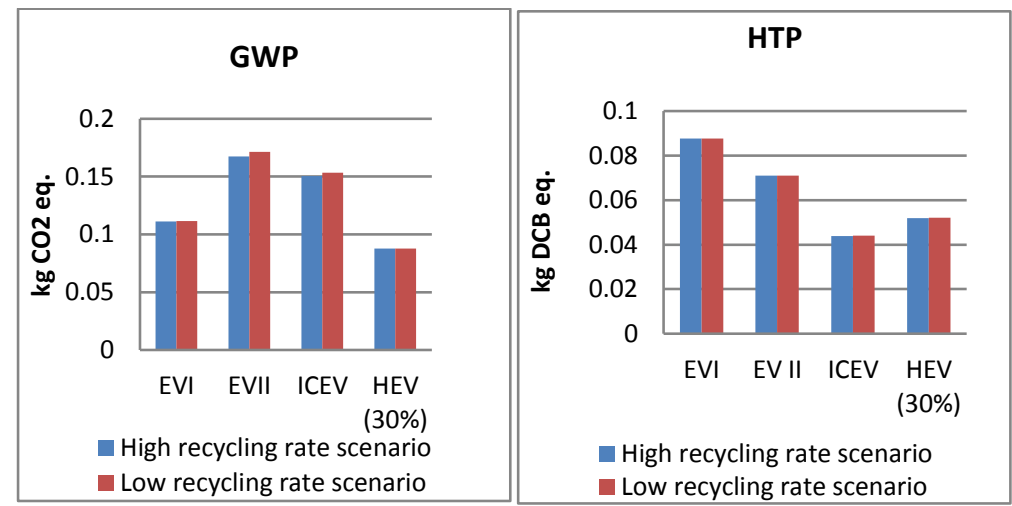

\subsection{Scenario analysis: hybridisation factor}

Figure 7 shows the GWP and the HTP for different hybridization factors: the trend for the two indicators is opposite. An increase in the ratio of the electric motion determines a decrease in the total GWP as opposed to what happens for the HTP. This result is due to the opposite trend of the HTP and GWP already shown in Figure 4 where the ICEV was the best option for the HTP and the EVs were the best options for the GWP. 

compared to the base scenario of the EVII as reported in Figure 4; on the other hand the HTP decreases up to $28 \%$ (for the HEV) with a decrease of the hybridisation factor when compared to the base scenario of EVI.

437
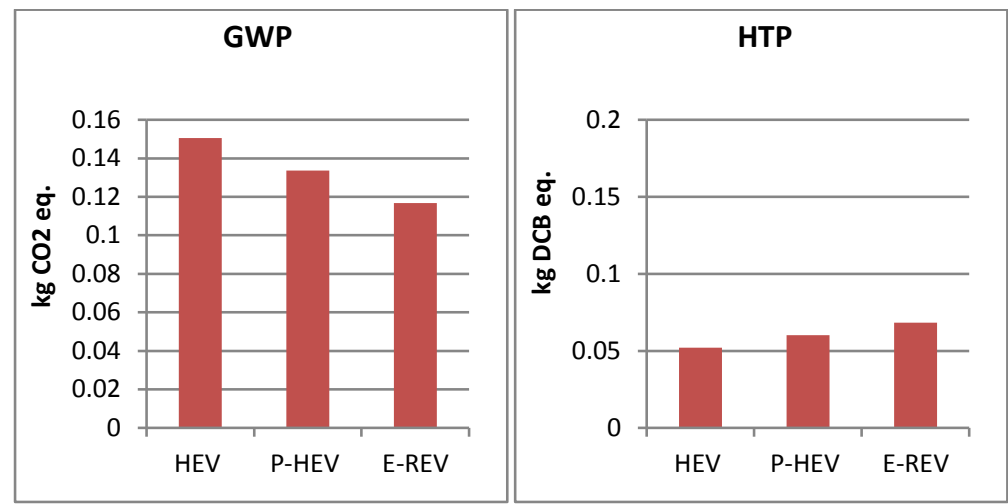

Figure 7 GWP and HTP for different hybridization factors

\subsection{Future energy mixes}

Finally, Figure 8 shows the ADP, HTP and GWP of the use phase models analysed for current and future energy mix in EU. For this case the GWP biogenic -that considers the uptake of the $\mathrm{CO}_{2}$ from atmosphere during the growth of the organic matter- is considered in order to analyse the effects of the biodiesel share in 2015 and 2050. For the GWP, both the ICEV and EV improve their performances in time and, therefore, the relative difference does not change between 2015 and 2050. The decrease of the GWP associated with the ICEV is due to the increased share of bio-diesel considered in the diesel mix and hence to the biogenic $\mathrm{CO} 2$ emissions. However, the GWP of the ICEV associated to the production of diesel increases (see red bars of ICEV in Figure 8); this is due to a higher environmental impact of bio-diesel production when compared to the fossil diesel, as later discussed. For the EV, the decrease of the GWP is due to the increased share of renewable making up the electricity mix in 2050.

In 2050, the EV represents the best option according to the total HTP. In fact, the HTP of the ICEV significantly increases over time according to an increase share of biodiesel in the mix. This point is further analysed in the discussion.

Future energy scenarios do not alter the relative trend of ICEV and EVs according to the ADP.

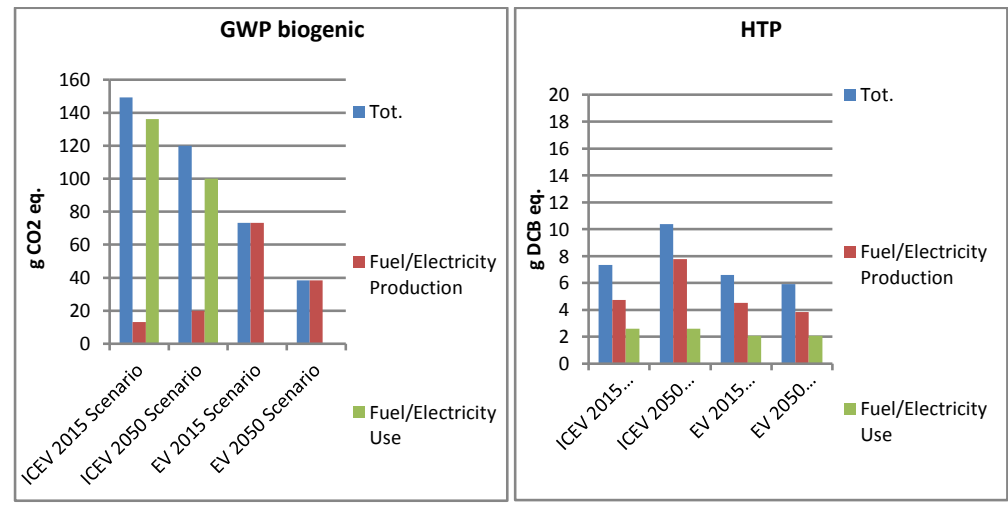




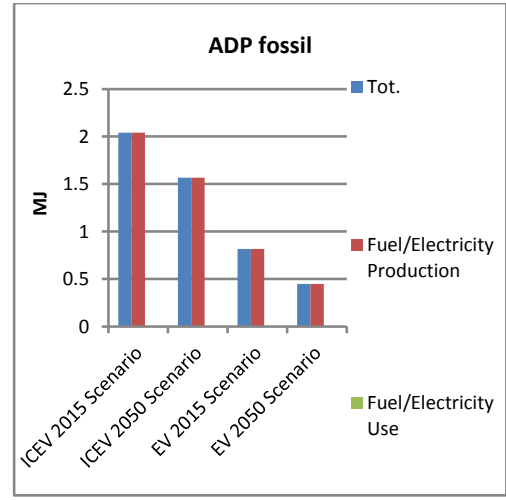

Figure 8 GWP, HTP and ADP of the ICEV and BEVI use phase for current and future energy mix.

This analysis only considered the impacts of different energy shares on the use phase, excluding a possible variation of the environmental impacts associated with the manufacturing and disposal phases. The calculations were not reported for the case of the manufacturing and use phase as the variation in the results was less strong than what shown for the use phase. However, lower energy requirements associated with a 'greener energy mix' also determined a decrease of the environmental impacts associated with both the manufacturing and disposal phases (lower avoided burdens would therefore be allocated for the recycling of materials in the disposal phase)

\section{Discussion}

The GWPs of the BEV for EVI and EVII and high recycling rate scenarios have been compared to the results reported by previous studies, as shown in Figure 9: the results presented in this study are within the range of GWPs already reported. The differences mostly stem from differing assumptions concerning manufacturing energy requirements and system boundaries. Data from older studies are placed in the upper range of the literature results; higher energy production efficiencies, advanced technologies and higher shares of renewable energy have contributed to the decrease of the total GWP of EVs. The same trend has been predicted to continue also for the future years according to the analysis reported for the future energy mix in 2050. 


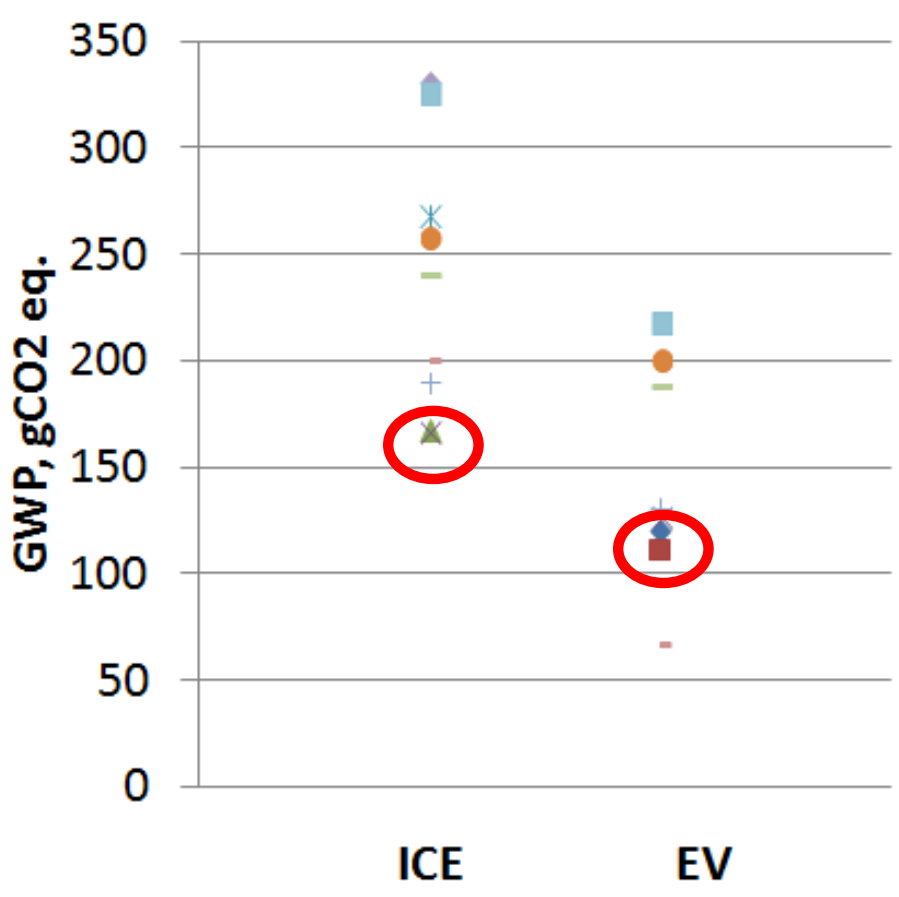

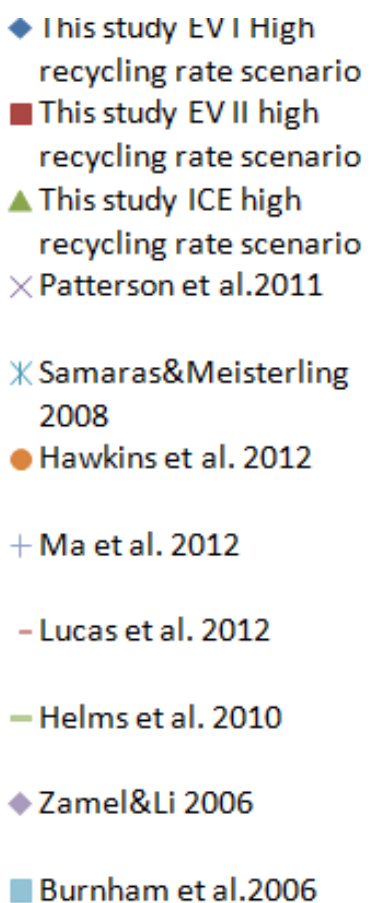

472

Figure 9 GWP: comparison with literature

When considering the entire life cycle of passenger vehicles, the gradual substitution of the ICEV fleet with the BEV fleet will determine a progressive reduction of the greenhouse gas emissions from the automotive sector thanks to the reduced emissions associated to the use phase. However, more technological developments are to be considered for the manufacturing phase, especially for the battery manufacturing. The results have shown that the high toxicological impacts are strictly linked with the exploitation of precious metals and production of chemical used in the battery manufacturing phase. Therefore, advanced processes and higher efficiencies are required to limit the impacts on water and human life. Although these are key points for the development of a $\mathrm{BEV}$ fleet, it has to be recognised that the use of conventional internal combustion engine vehicles might represent an even higher threats in future when considering the changing mix of fuels. Production of diesel from soybeans is known (Panichelli et al. 2008; Rocha et al. 2014) to determine a high human toxicity impact associated mainly to pesticide use during crop growth and fossil fuel consumption for oil extraction during biodiesel production.

This study presented a significant improvement to the modelling of the inventory data used to build the assessment, particularly for the disposal treatment. In fact, although publicly available data have been used for the inventory, this study has uniquely developed the model of the disposal phase according to a currently used industrial process. Furthermore, the attributional analysis associated with the consequential approach for the calculation of the avoided burdens adopted in this study, was able to identify future changes of the energy mix and project the environmental impacts of developing technologies.

\section{Conclusions}


The transport sector is one of the most challenging when tackling the targets on emissions reduction: developing technologies in the automotive industry, such as electric and fuel cell vehicles, associated with the use of lowcarbon content fuels are appealing solutions to potentially reduce greenhouse gas emissions. This study presented a life cycle assessment of an electric passenger vehicle using a Lithium-ion battery compared to an internal combustion engine vehicle and hybrid vehicles. A hot spot analysis was also performed to identify the phases of the entire vehicle life cycles that are firstly to be addressed to reduce the overall environmental impacts. Three major phases makes up the entire life cycle of the vehicles, the manufacturing, use and disposal. A further break down of the impacts associated to these phases has been reported in the hot

502 spot analysis. Two models for the manufacturing of the EV have been analysed according to different inventory 503 data.

504 The ICEV determines a higher total global warming than the BEVs: this is mostly due to the greater (by almost 505 50\%) amount of greenhouse gas emitted in the use phase. Conversely, the manufacturing phase of the BEVs is almost double that of the ICEV: the higher global warming of the EV manufacturing is explained by a more complex propelling system that includes the battery manufacturing. This is associated with the production and use of metals, chemicals and energy required in the systems. The same trend as the GWP was also shown for the ADP whereas the analysis of the HTP has shown that the total burden of EVs is higher than that of ICEVs. This result is linked with the use of metals and chemicals for the battery manufacturing.

511 The LCA methodology has been used to predict the environmental impacts of the ICEV and BEV for future EU 512 energy mix. The trend of the results have shown that the GWP is projected to decrease for both technologies but 513 advanced processes for manufacturing of biodiesel for ICEV and battery for BEV need to develop further to 514 significantly reduce the toxicity impacts of both systems.

515 Two different disposal scenarios have been analysed. In the base scenario, the vehicle fleet was totally assumed 516 to be disposed in EU. Conversely, in the low recycling rate model, the part of the vehicle fleet that leaves the 517 EU was considered to be sent to landfill outside the EU. A negligible variation of the results was shown for the 518 two cases and this highlighted how the disposal phase has a minor impact on the total environmental burdens.

519 Overall this study has shown how the EVs are a potential technology that can contribute to the decrease of GHG 520 emissions when compared with conventional fuel vehicles. However, the manufacturing phase still represents 521 the major impediment to the total performance of the technology. Hence, significant fundamental research has still to be developed on the subject: future energy mix and improvements of the technological efficiencies could

523 contribute to a reduction of the GWP of the BEV manufacturing phase decreasing the difference with the manufacturing phase of the ICEV.

525 
Aguirre K, Eisenhardt L, Lim C, et al (2012) Lifecycle Analysis Comparison of a Battery Electric Vehicle and a Conventional Gasoline Vehicle.

Baumann H, Tillman A-M (2004) The Hitch Hiker's Guide to LCA. An orientation in life cycle assessment methodology and application. Lund, Sweden, Studentlitteratur

Behrens A, Coulie C, Teusch J (2013) The Potential Evolution of the European Energy System to 2020 and 2050.

Clift R (2013) System Approaches: Life Cycle Assessment and Industrial Ecology. In: Pollution: Causes, Effects and Control, 5th edn. R.M. Harrison Royal Society of Chemistry, London,

Clift R (2006) Sustainable development and its implications for chemical engineering. Chem Eng Sci 61:41794187. doi: 10.1016/j.ces.2005.10.017

Clift R, Doig A, Finnveden G (2000) The application of life cycle assessment to integrated solid waste management. Process Saf Environ Prot 78:279-287.

Daimler AG (2009) Life cycle - Environmental certificate for the S-400 hybrid. Mercedes-Benz.

Dunn JB, Gaines L, BArnes, M. Sullivan J, Wang M (2012a) Material and Energy Flows iin the Materials Production, Assemble, and End-of-Life Stages of Automotive Lithium-Ion Battery Life Cycle.

Dunn JB, Gaines L, Sullivan J, Wang MQ (2012b) Impact of recycling on cradle-to-gate energy consumption and greenhouse gas emissions of automotive lithium-ion batteries. Environ Sci Technol 46:12704-10. doi: $10.1021 /$ es302420z

Egede P, Dettmer T, Herrmann C, Kara S (2015) Life Cycle Assessment of Electric Vehicles - A Framework to Consider Influencing Factors. Procedia CIRP 29:233-238. doi: 10.1016/j.procir.2015.02.185

Ellingsen LA-W, Majeau-Bettez G, Singh B, et al (2014) Life Cycle Assessment of a Lithium-Ion Battery Vehicle Pack. J Ind Ecol 18:113-124. doi: 10.1111/jiec.12072

Faria R, Marques P, Moura P, et al (2013) Impact of the electricity mix and use profile in the life-cycle assessment of electric vehicles. Renew Sustain Energy Rev 24:271-287. doi: 10.1016/j.rser.2013.03.063

Genikomsakis KN, Ioakimidis CS, Murillo A, et al (2013) A life cycle assessment of a Li-ion urban electric vehicle battery. In: 2013 World Electric Vehicle Symposium and Exhibition (EVS27). IEEE, pp 1-11

Goodenough JB, Park K-S (2013) The Li-ion rechargeable battery: a perspective. J Am Chem Soc 135:1167-76. doi: $10.1021 / \mathrm{ja} 3091438$

Graedel TE et al (2011) Recycling rates of metals A status report.

Hawkins TR, Singh B, Majeau-Bettez G, Strømman AH (2013) Comparative Environmental Life Cycle Assessment of Conventional and Electric Vehicles. J Ind Ecol 17:53-64. doi: 10.1111/j.15309290.2012.00532.x

Helmers E, Marx P (2012) Electric cars: technical characteristics and environmental impacts. Environ Sci Eur 24:14. doi: 10.1186/2190-4715-24-14

Hischier R, Gallen E (2007) Disposal of electric and electronic equipment (e-Waste).

IEA Bioenergy (2011) Bioenergy, Land Use Change and Climate Change Mitigation. http://www.ieabioenergy.com/wp-content/uploads/2013/10/Bioenergy-Land-Use-Change-and-ClimateChange-Mitigation-Background-Technical-Report.pdf. Accessed 1 Jun 2016

ILCD (2011) European Commission-Joint Research Centre - Institute for Environment and Sustainability: International Reference Life Cycle Data System (ILCD) Handbook- Recommendations for Life Cycle Impact Assessment in the European context., First. Publications Office of the European Union.

International Energy Agency (2011) Biofuel for transport roadmap. https://www.iea.org/publications/freepublications/publication/Biofuels_foldout.pdf. Accessed 15 Sep 2015

IPCC (2007) Climate Change 2007: The Physical Science Basis. Contribution of Working Group I to the Fourth 
Assessment. Report of the Intergovernmental Panel on Climate Change., Solomon, S. Cambridge University Press, Cambridge, United Kingdom and New York, NY, USA.

576

Leuenberger M, Frischknecht R (2010) Life Cycle Assessment of Battery Electric Vehicles and Concept Cars.

Majeau-Bettez G, Hawkins TR, Strømman AH (2011a) Life cycle environmental assessment of lithium-ion and nickel metal hydride batteries for plug-in hybrid and battery electric vehicles. Environ Sci Technol 45:4548-54. doi: 10.1021/es103607c

Majeau-Bettez G, Hawkins TR, Strømman AH (2011b) Life cycle environmental assessment of lithium-ion and nickel metal hydride batteries for plug-in hybrid and battery electric vehicles. Environ Sci Technol 45:4548-54. doi: 10.1021/es103607c

Manfredi S, Pant R (2011) Supporting environmentally sound decisions for waste management: A technical guide to Life Cycle Thinking (LCI) and Life Cycle Assessment (LCA) for waste experts and LCA practitioners. http://publications.jrc.ec.europa.eu/repository/bitstream/111111111/22582/1/reqno_jrc65850_lb-na24916-en-n_pdf_.pdf. Accessed 4 Mar 2015

Matheys J, Mierlo J Van, Timmermans J-M, Bossche P Van den (2008) Life-cycle assessment of batteries in the context of the EU Directive on end-of-life vehicles.

Mehlhart G, Merz C, Akkermans L, Jorgensen JJ (2011) European second-hand car market analysis Final Report.

Miljøbil Grenland (2012) Bill of materials. Porsgrunn, Norway. Accessed 15 Sep 2015

Nissan (2015) Nissan Leaf.

Notter DA, Gauch M, Widmer R, et al (2010) Contribution of Li-ion batteries to the environmental impact of electric vehicles. Environ Sci Technol 44:6550-6. doi: 10.1021/es903729a

Panichelli L, Dauriat A, Gnansounou E (2008) Life cycle assessment of soybean-based biodiesel in Argentina for export. Int J Life Cycle Assess 14:144-159. doi: 10.1007/s11367-008-0050-8

Pizzol M, Christensen P, Schmidt J, Thomsen M (2011) Eco-toxicological impact of "metals" on the aquatic and terrestrial ecosystem: A comparison between eight different methodologies for Life Cycle Impact Assessment (LCIA). J Clean Prod 19:687-698. doi: 10.1016/j.jclepro.2010.12.008

Rocha MH, Capaz RS, Lora EES, et al (2014) Life cycle assessment (LCA) for biofuels in Brazilian conditions: A meta-analysis. Renew Sustain Energy Rev 37:435-459. doi: 10.1016/j.rser.2014.05.036

Samaras C, Meisterling K (2008) Life cycle assessment of greenhouse gas emissions from plug-in hybrid vehicles: implications for policy. Environ Sci Technol 42:3170-6.

Spielmann M, Bauer C, Dones R, et al (2007) Transport service.

Sullivan JL, A. B, Wang M (2010) Energy-Consumption and Carbon-Emission Analysis of Vehicle and Component Manufacturing.".

Sullivan JL, L. G (2010) A Review of Battery Life-Cycle Analysis: State of Knowledge and Critical Needs.

Swiss Centre for Life Cycle Inventories (2014) Ecoinvent: the life cycle inventory data, Version 3.0. Swiss Centre for Life Cycle Inventories, Duebendorf.

Thinkstep (2015) GaBi 6 software-system and databases for life cycle engineering. Stuttgart, Echterdingen (see www.pe-europe.com).

Umicore (2015) Battery recycling. http://www.umicore.com/en/industries/automotive/umicore-batteryrecycling/. Accessed 14 Sep 2015

UNECE (2015) Climate Change and Sustainable Transport - Transport - UNECE. http://www.unece.org/?id=9890. Accessed 14 Sep 2015

Vadenbo C (2009) Prospective Environmental Assessment of Lithium Recovery in Battery Recycling.

Van den Bossche P, Vergels F, Van Mierlo J, et al (2006) SUBAT: An assessment of sustainable battery technology. J Power Sources 162:913-919. doi: 10.1016/j.jpowsour.2005.07.039 
619 Wietschel M, Plötz P, Kühn A, Gnann T (2013) Market evolution scenarios for electric vehicles.

620 World Business Council for Sustainable Development (2004) Mobility 2030: Meeting the challenges to 621 sustainability.

622 Zackrisson M, Avellán L, Orlenius J (2010) Life cycle assessment of lithium-ion batteries for plug-in hybrid electric vehicles - Critical issues. J Clean Prod 18:1519-1529. doi: 10.1016/j.jclepro.2010.06.004 